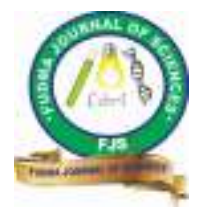

FUDMA Journal of Sciences (FJS)

ISSN online: $2616-1370$

ISSN print: 2645 - 2944

Vol. 4 No. 2, June, 2020, pp $8-15$

DOI: https://doi.org/10.33003/fjs-2020-0402-195

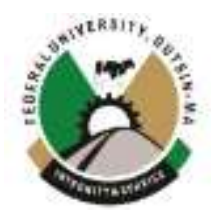

\title{
EFFECTS OF POULTRY MANURE AND WEED CONTROL METHODS ON GROWTH AND YIELD OF SESAME VARIETIES
}

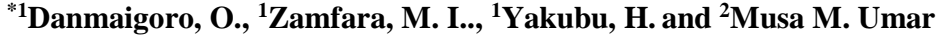 \\ ${ }^{1}$ Department of Crop Science, Faculty of Agriculture, Federal University Dutse. \\ ${ }^{2}$ Department of Extension, Faculty of Agriculture, Federal University Dutse. \\ *Corresponding Author email: odanmaigoro@gmail.com Tel: +2348108673326
}

\begin{abstract}
Field trials were conducted in 2017 and 2018 wet seasons at Federal University Dutse Teaching and Research Farm (Latitude 11 46, 39'N and Longitude 9 20, 30"E) in the Sudan Savanna of Nigeria. To evaluate performance of sesame varieties as affected by poultry manure and weed control methods. The treatments consisted of five weed control treatments (pre-emergence application of ButachlorEC50\%, hoe weeding at $3 \mathrm{WAS}+$ pre-emergence butachlor EC50\%, pre-emergence butachlor EC50\%+hoe weeding at 3 and 6WAS, hoe weeding @ 3 and 6WAS and weedy check), three level of poultry manure (5, 10, and 15t/ha) and three sesame varieties (Ben 01, Yandev 55 and Ben 04E. The treatments were laid out in split plot design and replicated three times. The results indicated that weed control methods had significant effect (0.05) on the sesame growth and seed yield comparable to hoe weeding control at 3 and 6WAS where plant height number of leaves, capsule number per plant and seed yield of sesame were significant higher with the application of butachlor plus hoe weeding at 3 and 6WAS compared to others weed control methods. Poultry manure application on sesame as $15 \mathrm{t} /$ ha gave taller plant height, more number of leaves, higher sesame dry weight, longer capsule length and seed yield of sesame than the other rates while Ben 01(455 and 1043 ) perform better than the others two varieties (Yandev 498, 756 and Ben4E 522 and 765 ) for 2017 and 2018 seasons. In conclusion, application of $15 \mathrm{t} / \mathrm{ha}$ poultry manure with pre emergence application of butachlor EC50\% plus two hoe weeding control gave the best yield of Ben 01 variety sesame.
\end{abstract}

Keywords: Manure, butachlor, plant height, number of capsule, seed yield of sesame

\section{INTRODUCTION}

Sesame (Sesamum indicum L.), a member of the Pedaliaceae family, is one of the ancient cultivated plants, mainly for its seeds as oil and food sources. It is an economically important crop widely cultivated in several countries (Ogbonna and UmarShaaba, 2011). The most popular specie is $S$. indicum which has hundreds of varieties and strains with considerable variations in size, form, and growth pattern, colour of flowers, seed size, seed colour and composition. Among the challenges facing sesame cultivation is the weed infestation especially at the earlier stage as sesame requires weed free condition for 50 to 60 days after planting (Langham et al. 2007). Consequently, the presence of weeds can reduce the sesame yield (Grichar et al. 2001). Reduction of up to $65 \%$ in sesame yield has been reported (Grichar et al. 2001). The traditional method of weed control, namely, hoe-weeding, is the commonest method of weed control by farmers in the Sudan Savanna Zone of Nigeria. This method is not only labour intensive, expensive and strenuous, but can also cause mechanical damage to growing branches and roots of plants. In addition to high cost, labour availability is uncertain, thus making timeliness of weeding difficult to attain, leading to greater yield loss (Adigun and Lagoke, 2003). A survey carried out by Ikuenobe et al. (2005) showed that majority of farmers using herbicides indicated savings in labour and cost of production, better weed control and higher crop yields. Most of the work done on chemical weed control in sesame has been limited to the Southern Guinea Savanna Zone of Nigeria and other parts of the world with agro-ecology different from that of the semi-arid zone of Nigeria, characterized by low, erratic, variable and unreliable rainfall, which affect the performance of herbicides. For example, Ndarubu et al. (2003), reported highest sesame yield and effective weed control with application of herbicide mixture of metolachlor + metobromuron at $1.0+1.0$ $\mathrm{kg}$ a.i./ha in the Guinea Savanna of Nigeria. The chemical usage shows a lot of inconsistencies in the phytotoxicity of herbicides on sesame. Some researchers have shown that sesame yield was increased by the application of metolachlor and trifluralin (Hussein et al. 1983) or was not affected by metolachlor (Grichar et al. 2001). In other studies, metolachlor adequately controlled weeds but caused unacceptable crop injury or reduced the sesame plant stands and caused sesame stunting when compared with the untreated check in one of two years (Grichar et al. 2009). 
As a result of the paucity of data on the use of herbicides in sesame production, it has made it necessary to evaluate some herbicides in this zone to find out not only how safe they are, but their effectiveness in the control of weeds to achieve higher yield in sesame (Imoloame, 2009). Diuron was reported to have reduced the yield or controlled weeds without significant reduction in the yield (Langham et al. 2007). In a related, effect of diuron application with pendimethalin and alachlor was dosespecific and greater phytotoxicity was noted with the highest dose (Beltrao et al. 1991).

Soils of the savannah regions are known to contain low nitrogen that are inadequate to sustain good growth and development of some crop plants. This was as a result of their sandy nature, continuous cropping and intensive grazing by livestock that left little or no crop residues to be incorporated into these soils. The non-application of fertilizer is the most important factors responsible for this low productivity. In order to maximize the production of sesame and the incomes of farmers, it has become necessary to look for other alternative strategies of production technology, mainly the adoption of proper fertilization (Ibrahim et al., 2008). Chemical fertilizers have been used for decades to increase crop yield. However, due to diverse socioenvironmental constraints relative to chemical fertilizers uses, current trends in sustainable agriculture are focused on organic sources of fertilizer (Scotti et al., 2015). The enhancing effect of manure is attributed to a gradual and more lasting release of a wide range of nutrient elements (N, P, K, micronutrients, etc.) to the soil (Amanullah et al., 2007). Poultry manure creates a favorable environment for root development. Zhen et al. (2014) also noted that large population of micro-organisms are introduced to the soil through organic manure which promoted $\mathrm{N}$ fixation and $\mathrm{P}$ solubilisation. Furthermore, the mixture of sawdust and poultry manure contributed to reduce the population of fungi in the soil. In order to increase the productivity of sesame by using poultry manure and enhance crop growth and development through chemical weed control, this study was carried out to evaluate the efficiency of chemical weed control methods and determine the response of sesame varieties to poultry manure application.

\section{MATERIAL AND METHOD}

The field trials were conducted during the wet seasons of 2017 and 2018 at Federal university Dutse, Teaching and Research

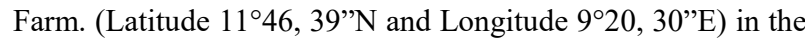
Sudan Savannah ecological zone of Nigeria. The experiment consists of three rates of poultry manure (5, 10 and 15tons/ ha), five weed control methods (two hoe weeding at 3 and 6WAS, butachlor, butachlor + hoe weeding at $3 \mathrm{WAS}$, butachlor + two hoe weeding at 3 and 6WAS and weedy check) and three varieties of sesame ( Ben 01, Yandev 55 and Ben 04E). The weed control treatments and poultry manure were signed to main plot while varieties to the subplot. The treatment ware laid out in a split plot design and replicated three times. The main plot size was $2 \mathrm{~m}$ by $2 \mathrm{~m}\left(4 \mathrm{~m}^{2}\right)$. The experimental area was discploughed and harrowed to a fine tilt. This was then followed by ridging at $40 \mathrm{~cm}$ and $30 \mathrm{~cm}$ within the ridges using animal mounted ridgers and the field marked into plots and blocks (replications). The plots were separated by $1.0 \mathrm{~m}$ unplanted boarder while replications were separated by $2.0 \mathrm{~m}$ unplanted alley. The poultry manure was incorporated into the ridges according to the treatment and left for two weeks before sowing

Sesame was sown at $30 \mathrm{~cm}$ within the row and $40 \mathrm{~cm}$ apart. The weed control methods were imposed based on the treatment. Five plants were tagged randomly within each plot during the plant growth at 3, 6, 9, and 12 WAS and at harvest and used to determine the parameters measured A plant height of five tagged plants in each plot was measured from base of the plant to its apex using meter rule and the means calculated and recorded. The number of leaves from each of the five tagged plants in each plot was counted and the means was calculated and recorded. Capsule lengths of five capsules tagged plant were measured with measuring tape and values were recorded. Number of capsules per plant was counted for five randomly selected plants in each net plot.

The crop was harvested at full maturity, seeds were separated out from the capsules, cleaned and dried in the sun to bring them to safety moisture content of seed and thereafter, the weight of the seeds was taken and converted to yield $\left(\mathrm{kg} \mathrm{ha}^{-1}\right)$. Data collected were subjected to analysis of variance (ANOVA) using Statistical Analysis System (SAS) 9.0 version and the significant means were compared using Duncan Multiple Range Test (DMRT) (Duncan, 1955).

\section{RESULT}

Plant height of sesame: Effect of weed control treatment, poultry manure and variety on the plant height of sesame was significant (Table 1). In 2017, application of butachlor EC 50\% + hoe weeding at 3 and 6WAS resulted significant taller plant which was statically similar to control (hoe weeding at 3 and 6WAS) while others weed control methods gave statistically shorter plant height at 6WAS. At 9WAS, all weed control methods gave statistically similar longer plant height of sesame except pre-emergence application of butachlor EC 50\% and the weedy check that had the shortest plant height. At 12WAS, similar trend was observed. However, in 2018, at 6WAS, application of pre-emergence butachlor EC50\%+ hoe weeding at 3 and 6WAS was observed to produce longest and similar plant height of sesame with control (hoe weeding 3 and 6WAS) than the other two weed control methods while the weedy check gave the shortest plant height. At 9WAS in 2018, there was no significant effect of weed control method on plant height. At 12WAS, all weed control methods resulted in statistically 
similar and longest plant height of sesame while the weedy check produced the shortest plant height.

Application of poultry manure resulted significant effect on the plant height of sesame only at the 12WAS, where 5t/ha and $10 \mathrm{t} / \mathrm{ha}$ of manure application gave similar plant height of sesame while $0 \mathrm{t} / \mathrm{ha}$ gave the shortest height similar trend was observed in 2018 .

Varietal response was significant at 12WAS in 2017 where Ben01 and Yandev55produced taller and similar plant height compare with Ben04E variety which had the shortest plant height. Furthermore in 2018, Ben01 was observed to give tallest plant height at all the sampling periods but at par with Yandev55 at 9WAS while Ben 04E had the shortest height.

Number of leaves: Effect of weed control methods poultry manure and variety was significant on the number of leaves of sesame (Table2). At 6WAS in 2017, all the weed control methods were observed to produce similar number of leaves of sesame while the weedy check gave the lowest number. Similar trend was observed in 9 and 12WAS. In 2018, effect of weed control was only significant at 6WAS where all the weed control methods produced statistically similar number of leaves per plant except hoe weeding at 3 and 6WAS which gave highest number of leaves while the weedy check produced the least number of leaves. Application of poultry manure effect on the number of leaves was significant. In 2107 at 9 and 12WAS, application of $15 \mathrm{t} / \mathrm{ha}$ of manure resulted in highest number of leaves per pant of sesame while $0 \mathrm{t} / \mathrm{ha}$ had the least number of leaves per plant. At $9 \mathrm{WAS}$ in 2018, application of $5 \mathrm{t} / \mathrm{ha}$ and $10 \mathrm{t} /$ ha produced no significant difference on number of leaves per plant but application of $15 \mathrm{t} / \mathrm{ha}$ of manure gave significantly higher number of leaves than other rates. There is nonsignificant effect of variety on the number of leaves of sesame per plant in 2017, however, in 2018, Ben 01 at 6WAS gave the highest number of leaves per plant while Yandev55 and Ben04E had statistically similar number of leaves per plant.

Number of capsules per plant: Effect of weed control methods poultry manure and variety was significant on the number capsules per plant (Table 3). In 2107, all weed control methods except application butachlor EC50\% which at par with butachlor+hoe weeding @3WAS, gave similar number of capsules per plant while the weedy check produced the least. In 2108 , , hoe weeding at 3 and 6WAS gave the highest number of capsules while the weedy check and butachlor EC 50\% produced the lowest number of sesame capsules. Application of poultry manure had significant effect on the number of capsules per plant of sesame in both seasons. In 2107, application of $15 \mathrm{t} /$ ha of poultry manure resulted in highest number of capsules while 5t/ha gave the lowest number and similar trend was observed in 2018. Ben 01 produced the highest number of capsules per plant in 2018.

Capsules length (cm): Effect of poultry manure and variety on capsule length of sesame was significant (Table 3). In 2017, all weed control methods were not significant on length of the capsules in both years while application of 10 and $15 \mathrm{t} / \mathrm{ha}$ of poultry manure was statistically similar on capsule length of sesame and 5t/ha gave the shortest length. In 2018, however application of $15 \mathrm{t} / \mathrm{ha}$ of manure gave the longest capsule length while application of 5 and 10 t/ha was statistically similar on capsule length.. Effect of variety was not significant in both seasons.

Yield of sesame (kg/ha): Effect of weed control methods and poultry manure application was not significant on the yield of sesame (Table 3). Ben 01 produced the highest yield of sesame among the three varieties

\section{DISCUSSION}

Application of poultry manure promoted vegetative growth in sesame in the study area. This consequently resulted to increase in number of capsules produced, better seed formation and filling which led to the higher seed yield recorded in plots that received manure treatments. Increase in number of leaves/plant was expected and this could have caused the increase in photosynthetic efficiency of the plant which translated to high yield observed in the experiment. Earlier study has shown that plant height and number of branches/plant have significant direct positive correlation with seed yield in sesame (Parameshwarappa et al., 2009). The same study also revealed that number of capsules/plant and number of seeds/capsule maintained positive linear relationship with seed yield in sesame. An experiment conducted in the northern guinea savanna area of Nigeria also showed that application of poultry manure in sesame production resulted to significant increase in sesame grain yield (Haruna. et al, 2011). In a similar study by Haruna et al., 2011 indicated that plant growth attributes such as plant height, number of branches/plant, stem girth, number of leaves plant as well as total dry matter yield were increased as a result of poultry manure application. Danmaigoro et al. (2015) reported a positive effect of organic manure application in sesame production.

Butachlor 50\%EC as a pre-emergence herbicide combined with hoe weeding at 3 WAS had the highest efficiency in reducing weed density and controlled grass and broadleaf weeds across the growing season. This might be due to long season effect exhibited by the herbicide The application of the postemergence herbicide individually had lower efficiency on weed control. The results of our present research imply that weeds are able to reduce sesame grain yield considerably by competing with the crop. Sesame yield losses due to its competing with weeds have been estimated up to $135 \%$ compared to the weedfree treatment (Balyan 1993). In most of the reports, it could be concluded that the highest sesame yield losses were due to its lack of competition to weeds at early growth stage. In this study, a low yield in post-emergence treatment was presumably caused by the lack of weed control in the early growth stage. As a result, sesame competed with weeds before the application of post- 
emergence herbicides. Thus, it is essential to use pre-emergence herbicides to control sesame weeds. Other research has shown sesame susceptibility to post-emergence herbicides but a toleration of haloxyfop (Langham 2008). The application of haloxyfop has been recommended where there is an outbreak of grass weed in the sesame field (Langham 2008). The herbicide alachlor was successful in controlling weeds without any damage to the sesame. Furthermore, the use of herbicides is more profitable than hoe-weeding in the production of most crops in Nigeria.

\section{CONCLUSION}

Application of $15 \mathrm{t} / \mathrm{ha}$ poultry manure with pre emergence application of butachlor EC50\% plus two hoe weeding control gave the best yield of Ben 01 variety sesame.

\section{REFERENCES}

Amanullah M. M., E. Somasundaram, K. Vaiyapuri and K. Sathyamoorthi (2007). Poultry manure to crops - a review, Agricultural Review: 28, (3), 216-222.

Adigun J.A., S.T.O. Lagoke (2003). Weed control in transplanted rainfed and irrigated tomatoes in the Nigeria Savanna. Niger. J. Weed Sci., 16: 24-30.

Beltrao, N.; Vieira, D., Nobrega, L. \& Santos, J. (1991). Effects of fertilizers, cultivar and weed control in sesame, Pesquisa Agropecuaria Brasilieira 26(5), 605-611.

Balyan, R. (1993). Integrated weed management in oilseed crops in India. Proc. India Sump Indian Soc. Weed Sci. 1, 317 323.

Danmaigoro. O., Abdulhamid, A and H. Jamilu: (2019):Effect of poultry manure and weed control method on growth and yield of sesame: Dutse Journal of Agriculture and food security(DUJAFS) 6.(1) 110-119

Duncan, B.D. (1955). Multiple Range and Multiple F test. Biometrics 11: 1-42Engin, Y, Emre, K, Seynus, F and Bulent, U. (2010). Assessment of selected criteria in sesame by using correlatio coefficient, path and factor analysis. Australian journal of crop science. 4(8) 598-602.

Grichar, W.; Sestak, D., Brewer, K., Besler, B., Stichler, C., \& Smith, D. (2001). Sesame(Sesamum indicum L.) tolerance and weed control with soil-applied herbicides. Crop Protect. 20, 389-394.

Grichar, W.; Sestak, D., Brewer, K., Besler, B., Stichler, C. \& Smith, D. (2007). Sesame (Sesamum indicum L.) tolerance with various postemergence herbicides. Crop Protect. 20, 685-689.
Grichar, W.; Besler, B., Dotray, P., Johnson, W. III, \& Prostko, E. (2009). Interaction of flumioxazin with dimethenamid or metolachlor in peanut (Arachis hypogaea). Peanut Sci. 31, 1216.

Grichar, W.; Dotray, P. D. Langham (2009). Sesame (Sesamum indicum L.) response to preemergence herbicides. Crop Protect. 28, 928-933.

Haruna IM, Aliyu L, Olufajo OO, Odion EC (2011). Growth of sesame (SesamumindicumL.) as influenced by poultry manure, nitrogen and phosphorus in Samaru, Nigeria. AmericanEurasian J. Agric. \& Environ. Sci. 10(4):561-568.

Hussein, M.; El-Hatlab, A., Abd-El Raouf, M., Shaban, S. \& ElDeek, M. (1983). Effect of soil herbicides on weeds, yield and quality of sesame, Sesamum indicum L. Z. Acker. Pflanzenbou $152,173-185$.

Ibrahim M., A. Ul-Hassan, M. Iqbal and E. E. Valeem..(2008). Response of wheat growth and yield to various levels of compost and organic manure, Pakistan Journal of Botany: 40 (5) 2135-2141.

Imoloame E.O. (2009). Effects of pre- and post- emergence herbicides on weed infestation and productivity of sesame (Sesamum indicum L.) in a Sudan Savanna zone of Nigeria. Ph.D Thesis, Department of Crop Production University of Maiduguri, Maiduguri, p. 145.

Ikuenobe C.E., Fadayomi I.O., Adeosun J.O, Gworgwor N.A., Melifonwu A.A., Ayeni A.O., (2005). State of adoption of improved weed control technologies by farmers in three agroecological zones of Nigeria. Nig. J. Weed Science. 18:1 - 19.

Parameshwarappa K. G.(2009) Studies on genetic variability and character association in germplasm collection of sesame (Sesamum indicum L.). Karnataka Journal of Agricultural Sciences: 22, (2), 252-254.

Langham, D; Grichar, W. P. Dotray (2007). Review of herbicide research on sesame(Sesamum indicum L.). Version 1. www.sesamegrowers.org, accessed Aug, 2010.

Langham, D.(2008). Growth and Development of Sesame. Sesaco Corp. 42 p.

Ndarubu A.A., Adejonwo K.O., Adigun J.A., U. F. Chiezey (2003). Effects of weed control treatments and interrow spacing on the growth and yield of sesame (Sesamum indicum L.). Niger. J. Weed Sci., 16: 15-23.

Ogbonna P. E. and Y. G. Umar-Shaaba (2011). Yield responses of sesame (Sesamium indicum L) to rates of poultry manure application and time of planting in a derived savannah ecology 
of south eastern Nigeria, African Journal of Biotechnology, 10( 66,): 14881-14887.

Parameshwarappa SG, Palakshappa MG, Salimath PM, Parameshwarappa KG (2009). Studies on genetic variability and character association in germplasm collection of sesame (SesamumindicumL.). Karnataka J. Agric. Sci. 22(2):252-254.
Scotti R., G. Bonanomi, R. Scelza, A. Zoina and M. A. Rao. (2015). Organic amendments as sustainable tool to recovery fertility in intensive agricultural systems, Journal of Soil Science and Plant Nutrition, 15(2) :333-352. 
Table 1: The effect of weed control treatments, poultry manure and variety on plant height $(\mathrm{cm})$ of sesame at Dutse in 2017 and 2018 seasons.

PLANT HEIGHT (CM)

2017

Treatment Rate

Weed Control (W)

Butachlor

(Kg.a.i/ha)

Butachlor +hoe weeding@3WAS

Butachlor +hoe weeding @ 3 \& 6

Hoe weeding @3 \&6WAS

Weedy check

$\mathrm{SE} \pm$

Poultry Manure (M) (t/ha)

5

10

15

SE \pm

Variety

(V)

Ben01

Yandev55

Ben04E

SE \pm

Interaction

$$
\begin{gathered}
\mathrm{W} \times \mathrm{M} \\
\mathrm{W} X \mathrm{~V} \\
\mathrm{~V} \mathrm{x} \mathrm{M} \\
\mathrm{W} \mathrm{xMxV}
\end{gathered}
$$

\begin{abstract}
6WAS
\end{abstract}
9WAS

12WAS

6WAS

9WAS

12WAS

1=.WAS: Weeks after sowing.

\begin{tabular}{|c|c|c|c|c|c|}
\hline $22.88 b$ & $77.80 \mathrm{~b}$ & $155.94 b$ & $19.11 b c$ & 87.1 & $136.5 \mathrm{a}$ \\
\hline $23.33 b$ & $110.37 \mathrm{a}$ & $163.63 \mathrm{ab}$ & $19.44 b c$ & 75.3 & $134.1 \mathrm{a}$ \\
\hline $30.00 \mathrm{a}$ & $109.80 \mathrm{a}$ & $179.41 \mathrm{a}$ & $21.40 \mathrm{ab}$ & 86.8 & $124.7 \mathrm{a}$ \\
\hline $29.19 \mathrm{a}$ & $106.80 \mathrm{a}$ & $165.56 \mathrm{ab}$ & $23.30 \mathrm{a}$ & 88.5 & $127.5 \mathrm{a}$ \\
\hline $21.65 b$ & $66.40 \mathrm{~b}$ & $129.94 \mathrm{c}$ & $15.80 \mathrm{c}$ & 87.8 & $107.0 \mathrm{~b}$ \\
\hline 0.74 & 12.27 & 5.69 & 1.64 & 5.03 & 5.25 \\
\hline 21.19 & 87.33 & $140.88 b$ & 21.8 & 79.4 & $118.5 b$ \\
\hline 24.71 & 102.19 & $165.95 \mathrm{a}$ & 19.4 & 88.13 & $128.5 \mathrm{ab}$ \\
\hline 27.32 & 91.96 & $169.38 \mathrm{a}$ & 19.3 & 87.93 & $130.95 \mathrm{a}$ \\
\hline 1.24 & 20.45 & 9.48 & 1.27 & 3.90 & 4.06 \\
\hline 26.36 & 96.25 & $165.53 \mathrm{a}$ & $23.7 \mathrm{a}$ & $91.78 \mathrm{a}$ & $135.42 \mathrm{a}$ \\
\hline 24.00 & 95.01 & $163.49 \mathrm{a}$ & $17.9 \mathrm{~b}$ & $87.75 \mathrm{a}$ & $119.75 b$ \\
\hline 25.87 & 90.23 & $147.19 b$ & $18.9 \mathrm{~b}$ & $75.89 \mathrm{~b}$ & $122.75 b$ \\
\hline 1.24 & 20.45 & 9.48 & 1.27 & 3.90 & 4.06 \\
\hline $\mathrm{NS}^{3}$ & NS & NS & NS & NS & NS \\
\hline NS & NS & NS & NS & NS & NS \\
\hline NS & NS & NS & NS & NS & NS \\
\hline NS & NS & NS & NS & NS & NS \\
\hline
\end{tabular}

$2=$ Means followed by the same letter(s) within a column of each sets of treatments group are not significantly different at P $\leq 0.05$ using DMRT.

$3=$ NS: No significant

2018 
Table 2: $\quad$ The effect of weed control treatments, poultry manure and variety on plant height $(\mathrm{cm})$ of sesame at Dutse in 2017 and 2018 seasons.

\section{NUMBER OF LEAVES}

2017

6WAS

\begin{tabular}{r} 
Treatment Rate \\
\hline Weed Control $(\mathbf{W})$ \\
(Kg.a.i/ha)
\end{tabular}

Butachlor

Butachlor +hoe Weeding@3WAS

Butachlor +hoe weeding @ 3 \& 6

WAS

Hoe weeding@3\&6WAS

Weedy check

$\mathrm{SE} \pm$

Poultry Manure (M) (t/ha)

5
10
15
SE \pm

Variety

$\mathrm{SE} \pm$

(V)

Ben01
Yandev5

Ben04E

$\mathrm{SE} \pm$

Interaction

$\mathrm{W} \times \mathrm{M}$
$\mathrm{W} \times \mathrm{V}$
$\mathrm{V} \times \mathrm{M}$
$\mathrm{W} \times \mathrm{xxV}$

0.37

2018

$\begin{array}{llllll}15.22 \mathrm{ab}^{2} & 85.56 \mathrm{a} & 115.22 \mathrm{a} & 25.3 .3 \mathrm{~b} & 82.5 \mathrm{a} & 191.81 \mathrm{a}\end{array}$

$\begin{array}{llllll}16.33 \mathrm{ab} & 84.89 \mathrm{a} & 125.33 \mathrm{a} & 31.1 \mathrm{bc} & 67.6 \mathrm{a} & 133.0 \mathrm{a}\end{array}$

\begin{tabular}{|c|c|}
\hline $15.0 \mathrm{ab}$ & \\
\hline
\end{tabular}

$\begin{array}{llllll}19.44 \mathrm{a} & 88.56 \mathrm{a} & 112.22 \mathrm{a} & 38.2 \mathrm{a} & 79.2 \mathrm{a} & 176.22 \mathrm{a}\end{array}$

$\begin{array}{llllll}14.22 \mathrm{~b} & 54.56 \mathrm{~b} & 82.22 \mathrm{~b} & 24.4 \mathrm{c} & 83.6 \mathrm{a} & 197.890 \mathrm{a}\end{array}$

$13.92 \quad 7.55$

2.57

$8.09 \quad 8.9$

$\begin{array}{llllll}16.73 & 71.93 \mathrm{c} & 85.67 \mathrm{c} & 31.4 & 69.2 \mathrm{~b} & 160.9 \mathrm{a}\end{array}$

$14.87 \quad 75.93 b$

$118.80 \mathrm{~b}$

29.9

$71.7 \mathrm{~b}$

$93.5 \mathrm{a}$

$195.6 \mathrm{a}$

$\begin{array}{llll}16.53 & 83.93 \mathrm{a} & 135.12 \mathrm{a} & 29.0\end{array}$

$\begin{array}{llll}0.62 & 2.21 & 12.58 & 1.99\end{array}$

$$
6.27
$$

$176.9 \mathrm{a}$

6.9

$\begin{array}{llllll}16.53 & 79.40 & 112.8 & 37.46 \mathrm{a} & 84.9 \mathrm{a} & 202.9 \mathrm{a}\end{array}$

$\begin{array}{llllll}14.87 & 80.47 & 115.59 & 27.24 \mathrm{~b} & 69.8 \mathrm{a} & 154.33 \mathrm{a}\end{array}$

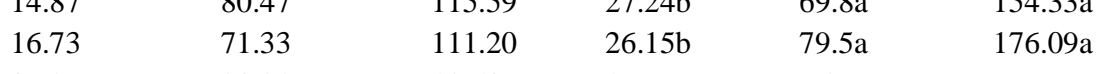

$\begin{array}{llllll}0.62 & 23.21 & 12.58 & 1.99 & 6.27 & 6.9\end{array}$

$1=$.WAS: Weeks after sowing

$2=$ Means followed by the same letter(s) within a column of each sets of treatments group are not significantly different at P $\leq 0.05$ using DMRT.

$3=\mathrm{NS}$ : No significant 
Table 3: $\quad$ The effect of weed control treatments, poultry manure and variety on number of capsule, length of capsule and seed yield of sesame at Dutse in 2017 and 2018 seasons.

\begin{tabular}{|c|c|c|c|c|c|c|c|}
\hline \multirow[b]{2}{*}{ Treatment } & \multirow[b]{2}{*}{ Rate } & \multicolumn{3}{|c|}{ NO OF CAPSULES } & \multicolumn{2}{|c|}{ CAPSULE LENGTH } & \multirow{2}{*}{$\begin{array}{l}\text { YIELD } \\
2018\end{array}$} \\
\hline & & 2017 & 2018 & 2017 & 2018 & 2017 & \\
\hline \multicolumn{8}{|l|}{ Weed Control (W) } \\
\hline \multicolumn{8}{|c|}{ (Kg.a.i/ha) } \\
\hline Butachlor & & $92.00 \mathrm{~b}^{1}$ & $56.4 \mathrm{~b}$ & 2.94 & 3.06 & 552.60 & 834.7 \\
\hline Butachlor +hoe wee & ding @3WAS & $102.67 \mathrm{ab}$ & $76 . .7 \mathrm{ab}$ & 3.07 & 2.93 & 589.40 & 792.7 \\
\hline Butachlor +hoe wee & ding @3 \&6 & $108.67 \mathrm{a}$ & $73.4 \mathrm{ab}$ & 3.12 & 3.05 & 475.00 & 920.0 \\
\hline \multicolumn{8}{|l|}{ WAS } \\
\hline Hoe weeding@3\&6 & NAS & $111.33 \mathrm{a}$ & $85.5 \mathrm{a}$ & 2.93 & 2.08 & 432.90 & 966.5 \\
\hline Weedy check & & $67.22 \mathrm{c}$ & $52.73 b$ & 3.04 & 2.97 . & 410.30 & 762.6 \\
\hline & $\mathrm{E} \pm$ & 5.00 & 8.87 & 0.01 & 0.1 & 16.66 & 99.5 \\
\hline \multicolumn{8}{|c|}{ Poultry Manure (M) (t/ha) } \\
\hline & 5 & $65.13 \mathrm{c}$ & $62.7 \mathrm{c}$ & $2.80 \mathrm{~b}$ & $2.93 b$ & 446.33 & 752.1 \\
\hline & 10 & $103.20 \mathrm{~b}$ & $65.1 b$ & $3.12 \mathrm{a}$ & $2.96 \mathrm{~b}$ & 533.67 & 865.9 \\
\hline & 15 & $120.8 \mathrm{a}$ & $78.7 \mathrm{a}$ & $3.15 \mathrm{a}$ & $3.10 \mathrm{a}$ & 496.13 & 865.0 \\
\hline & $\mathrm{E} \pm$ & 8.34 & 6.87 & 0.01 & 0.1 & 99.44 & 948.0 \\
\hline \multicolumn{8}{|l|}{ Variety } \\
\hline & Ben01 & 90.53 & $95.84 \mathrm{a}$ & $3.03 \mathrm{ab}$ & 2.96 & 455.33 & $1043.3 \mathrm{a}$ \\
\hline & Yandev55 & 97.00 & $52.06 \mathrm{~b}$ & $2.91 \mathrm{~b}$ & 3.05 & 498.47 & $756.8 \mathrm{~b}$ \\
\hline & Ben04E & 101.6 & $58.57 \mathrm{~b}$ & $3.13 \mathrm{a}$ & 2.908 & 522.33 & $765.9 \mathrm{~b}$ \\
\hline & $\mathrm{E} \pm$ & 8.34 & 6.87 & 0.01 & $0 . .1$ & 2699.44 & 77.0 \\
\hline \multicolumn{8}{|l|}{ Interaction } \\
\hline & $\mathrm{W} \times \mathrm{M}$ & $\mathrm{NS}^{2}$ & NS & NS & NS & NS & NS \\
\hline & W XV & NS & NS & NS & NS & NS & NS \\
\hline & Vx M & NS & NS & NS & NS & NS & NS \\
\hline & $N \mathrm{xMxV}$ & NS & NS & NS & NS & NS & NS \\
\hline
\end{tabular}

$1=$ Means followed by the same letter(s) within a column of each sets of treatments group are not significantly different at P $\leq 0.05$ using DMRT.

2=NS: No significant

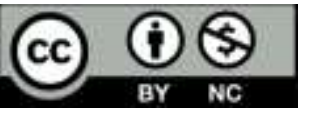

(C2020 This is an Open Access article distributed under the terms of the Creative Commons Attribution 4.0 International license viewed via https://creativecommons.org/licenses/by/4.0/ which permits unrestricted use, distribution, and reproduction in any medium, provided the original work is cited appropriately. 